\section{Seminarios de Nefrología Pediátrica de la Universidad de Miami}

Hemos recibido la invitación a participar en $\operatorname{los} 38^{\circ}$ Seminarios en Nefrología Pediátrica de la División de Nefrología Pediátrica, Miller School of Medicine, Universidad de Miami.

Este tradicional evento organizado por los Drs. José Strauss y Gastón Zilleruelo, ha representado desde hace muchos años una excelente herramienta de actualización para muchos pediatras y nefrólogos infantiles de nuestro país, los cuales han asistido apoyados por becas que pueden ser consultadas en las direcciones adjuntas.

La variedad de los temas tratados, desde aspectos de fisiología renal hasta terapias de sustitución en Enfermedad Renal Crónica, por prestigiados profesores expertos en el área, han hecho de este evento una tradición entre los interesados en la nefrología infantil en Chile y otros países del orbe.

Agradecemos al Dr. Gaston Zilleruelo su gentil aporte y esperamos una importante asistencia de parte de pediatras y nefrólogos de nuestro medio.

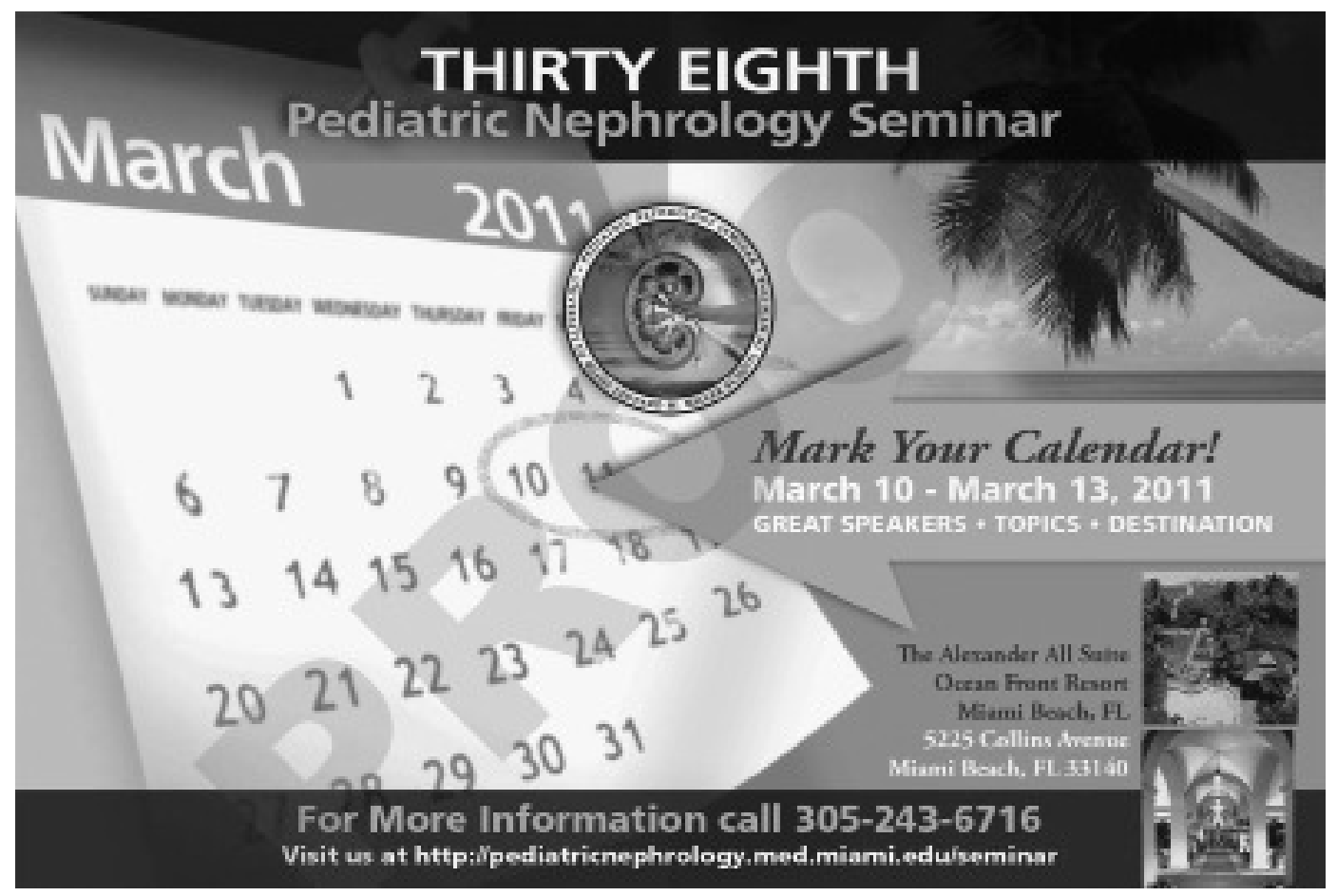

